\title{
Born into a World of Hostility and Contradiction: The Role of Mary-Anne Elizabeth Plaatjies-Van Huffel in URCSA
}

\author{
Selaelo Thias Kgatla \\ https://orcid.org/0000-0003-2703-3198 \\ University of South Africa \\ kgatla@mweb.co.za
}

\section{Abstract}

Mary-Anne Elizabeth Plaatjies-Van Huffel was born, bred and ordained as a minister of the word and sacraments in a notoriously patriarchal society. Besides the racial yoke of apartheid in the country of her birth, she also had to carry the burden of sexism, misogyny, machismo and marianismo in her daily life. Without compromise, but with a deep sense of gentleness, boldness and respect, she confronted and spoke the truth to those who held important leadership positions. Plaatjies-Van Huffel demanded a moral response from church leadership to the oppression of women in the church instead of an expedient, easy or selfish response. She was the first woman to be ordained in and appointed to the leadership of the church after a long wait for ordination. Her confrontation of patriarchy and its surrogates carried a connotation of bravery, and of risk to her career, reputation and livelihood. After her admission to the full ministry of the church, she climbed the ranks as a church leader, both locally and internationally. This article articulates Plaatjies-Van Huffel's work, role and contribution in her ministry within the Uniting Reformed Church in Southern Africa (URCSA) and in the ecumenical movement until her untimely death on 19 May 2020.

Keywords: Mary-Anne Elizabeth Plaatjies-Van Huffel; ordination; patriarchy; oppression; ministry; ecumenism

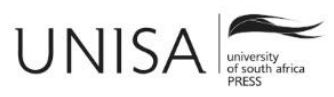




\section{Introduction}

The South African church history cannot fully be accentuated without appreciating the lives, struggles and contributions of black women. Although the tripartite oppression of women in the country has remained vicious and unrelenting, even after the struggle for the liberation of black people, there are women of note whose lives and contributions should be written in indelible ink for future generations. Plaatjies-Van Huffel is one of the heroines who have left a remarkable legacy in the Uniting Reformed Church in Southern Africa (URCSA). Through her ministry as a minister of the word and sacraments, leadership in local and international organisations, and illustrious academic career, she contributed immensely to women's emancipation and empowerment in the country.

Mary-Anne Elizabeth Plaatjies was born in Prieska in the Northern Cape province of South Africa in 1959 during the heyday of apartheid, when the policy of separateness was ruthlessly implemented both on state and ecclesiastical levels. She matriculated in 1977, and then enrolled at the University of the Western Cape and trained to become a minister of the word and sacraments in the then Dutch Reformed Mission Church (DRMC). In November 1992, she was ordained as the first woman minister in that church, 10 years after the DRMC had decided to open positions to women (Flaendorp 2014; Plaatjies-Van Huffel 2011; 2019). She paved the way for many other women, both laity and ordained, in the ministry of the church. However, her ordeal on a lonely road in her ministry was perverted in the South African context by three burdens: the apartheid system; patriarchal domination in both the society and the church; and gender insensitivity. In her academic writing and from the pulpit, she aptly denounced these three systems. Her prophetic voice was viewed by some hegemonic powers as irrelevant, myopic, and wrongly placed. Women who violate patriarchal norms and expectations, who are not serving male interests in the way they are expected to, always receive harsh treatment from the system (Manne 2020).

This article briefly unmasks the three contexts in which women like Plaatjies-Van Huffel had to work and lead their lives. It accentuates three broad areas of exploitation and domination of women by a male-dominated environment: 1) the apartheid system that stripped away their rights and dignity; 2) the religious systems that justified the docility of "Others"; and 3) the personal struggle Plaatjies-Van Huffel waged in URCSA in order to speak to the powers that be.

\section{Methodological Considerations}

Deciding on an appropriate research methodology is not an easy task, especially for male qualitative researchers because of the inherent subjectivity and cultural conditionality they have been coached in. For that reason, in this study, I confine myself to a mixture of two interrelated but different methodological approaches, intersectionality and feminist biographical methodologies, to disentangle the problem. Aida Harhey Wingfield (2009) defines intersectionality theory as a complex, cumulative 
way in which the effects of multiple forms of discrimination (such as racism, sexism, and classism) combine, overlap, or intersect; especially in the experiences of marginalised individuals or groups such as women and children. Coaston (2019), drawing on Crenshaw, and echoing what Wingfield has intimated, discusses the theory of intersectionality as thinking about how inequalities persist, and notes that categories like gender, race, and class are best understood as overlapping and mutually constitutive rather than isolated and distinct.

Popadiuk (2004) describes feminist biographical methodology as the second theory of feminist investigation and an in-depth interpretive methodology that is useful for research in the social sciences. As a qualitative method, it is excellent for analysing individual narratives of participants' lives in relation to the larger cultural matrix of the society in which they live. The feminist biographical methodology relies on interviews for data collection; in the case of people who have passed on, personal journals, official documents, academic texts and cultural evidence are vital sources.

The strength of mixing these two methods include the depth, context and meaning found in their application, where the inclusion of women's experiences and voices and their marginalisation are maintained (Popadiuk 2004; Wingfield 2009). Both methods provide depth, context and meaning to the phenomenon under research. The two approaches seek to acquire an inside understanding of the participants' definition of the situation by "grasping the subjective consciousness or intent of the actor from the inside" (Popadiuk 2004; Wingfield 2009). They address women's experiences in particular, as women have historically been "silenced, restricted, and dominated by the patriarchal society, that hides so many truths in order to subjugate women" (Pirani 1992).

\section{Under the Yoke of the Apartheid System}

Plaatjies-Van Huffel was born during the height of the apartheid regime in South Africa, when grand apartheid had been implemented and "perfected." The system of separateness was ruthlessly introduced after becoming institutionalised through the enactment of parliamentary laws, following the 1948 victory of the Nationalist Party under the leadership of Dr Daniel Francois Malan. At the time of Plaatjies-Van Huffel's birth, the grand apartheid policy of segregation in every sphere of life was enforced. Following the Group Areas Act of 1950 and associated legislation, black people were pushed to the margins of society and disenfranchised. Motives for self-preservation, self-interest, self-identity and cultural superiority prevailed and superseded the biblical "love for the neighbour" (Kgatla and Magwira 2015). 
According to Dr Hendrik Verwoerd, who was regarded as the architect of apartheid, ${ }^{1}$ "throwing together different communities into one common society in a multiracial state would mean racial suicide for white South Africans" (Johnson 1994, 157). This stance reinforced and served as a seedbed for the entire white community, including the Dutch Reformed Church's (DRC) mission policy of separate churches for the blacks, coloureds and Indians. On the political level, a form of separate self-governance for blacks, coloureds and Indians (Race Relations Survey 1962-1977) was introduced along the lines of the ruling political policies. In line with this policy, D. F. Malan told apartheid patriots at the Voortrekker Monument in Pretoria in December 1949 that it was the duty of white people to sustain "white Christianity by acting as 'guardians over the non-whites"” (Kgatla and Magwira 2015). This ideal would be maintained through "paramountcy" and "racial purity." Such statements were part of the legacy of the 1950 Group Areas Act and many other laws that followed and defined the world in which Plaatjies-Van Huffel was born.

At that stage, many countries around the world came together to try to help South Africa recognise the danger of apartheid, but even after the United Nations meetings, that not only warned the South African government about the contradictions of apartheid but also applied sanctions, no positive results were achieved (South African History Online, "South Africa Celebrating 20 Years of Democracy" 2019). Despite this external pressure and continuous resistance from within the country, black people continued to suffer under the yoke of apartheid, but women were even worse off, as they continued to bear the triple oppression of race, gender and sexism. By and large, the history of women's aspiration, their struggle for freedom from oppression, for community rights and, importantly, for gender equality, were mostly ignored within the South African political and ecclesiastical landscape (South African History Online 2019). Not only did the discourse lean heavily towards white political and economic interest to the detriment of black people, but it also focused on the achievements of men (often on their military exploits or leadership ability), virtually leaving women out of South African history (South African History Online 2019), and marginalising their contribution to the liberation struggle.

Despite the many obstacles in their path, women throughout the country put their names to petitions and thus indicated anger and frustration at having their freedom curtailed by apartheid laws. Their bravery (at the risk of official reprisals including arrest, detention and even bannings), can be appreciated through the lives of the likes of Plaatjies-Van Huffel. Their organisational skills, their community-consciousness, their resistance to "staying at home," their tenacity in making significant changes to a way of life that discriminated against them primarily because of their race, but also because of their class and their gender, are all noteworthy (South African History Online 2019). Black people were given negative connotations like non-white, non-European and, by

1 "How Should South Africa Remember the Architect of Apartheid?" https://www.smithsonianmag.com/history/how-should-south-africa-remember-architect-apartheid$180960449 /$. 
definition, non-something, before they could be something. Women were regarded as non-white, non-something and non-male persons. Although they were straddling at a lower level of less human, they emerged from non-persons to something worth appreciating. They were carrying the burdens of being women, and thus second-class, non-white, non-citizens of the country, and non-men in society. Their description fitted the ancient Jewish conceptualisation of women as the "Other" and the prayer of the average (Jewish) man, who was obligated to recite three blessings daily, captured aptly by Korn, Lander, and Lander (2010). These prayers expressed gratitude for one's station in life through the negative statements: "Thank God that I am not a gentile, a woman, or a slave" (Korn et al. 2010). To be a woman was a curse, a burden and an embarrassment in society. Their greatest fault was that they had been born women - as if they chose to be women. They had sinned and were cursed before they were born.

\section{Patriarchy as a Defining System in the Christian Religion}

In this research, it is argued that patriarchy is orchestrated from community, political, cultural, economic and religious conceptualisations (Kgatla 2020). Feelings such as fear, hatred, guilt, jealousy, pain, grief, confusion, lust, and hunger are at the centre of patriarchal conceptualisation (Ally 2015; Goloba-Muteni 2005; Parrinder 1963). As a system constructed by humans and perfected by men, patriarchy serves men's interests, in particular in defining gender roles. It is the bedrock of its surrogates' sexism, misogyny and negative masculinity. The system is universally responsible for the treatment of, even the punishment of, women who appear to be challenging such stereotypes (Kgatla 2020). Women are often punished because of their failure to perform to the expectations of their male counterparts (Manne 2020). In patriarchy, the male members of society hold primary power and prominence in roles related to political, social, economic and cultural leadership, which include moral authority, social privilege, and all spheres of control and power (Weldon 2019). It is a determining force of how society is shaped and functions. The consequence of the stereotypical framing of women is that it undermines trust, intimacy, social cohesion and the building of human capital (Kgatla 2020). At times, in the grander scheme of things, patriarchy poses as an altruistic system while concealing its menace of subtle manipulation of women and children (Kgatla 2019). It defines a general structure in which men have power over women, and where power has some level of privilege to which women and children are not entitled (Napikoski 2020).

What, then, was the position of women in the South African society in the 1960s, when Plaatjies-Van Huffel was born? The answer is that black women in traditional African societies and similarly, white women in the settler society, were subordinate to men and, in black societies, doubly oppressed. The position of women was inferior; the men took all the major decisions both in society at large and within the home. To date, despite the democratic gains the country has made since 1994, South African society remains notoriously patriarchal. Legislation that has been enacted to protect and empower women has, in practice, had little impact. Behind gender-based violence in the country 
lie the drivers of patriarchy, sexism, misogyny, machismo, marianismo, and masculinity (Kgatla 2020).

Patriarchy depends on the submissiveness of "loving" mothers (Manne 2016a\&b) and sometimes operates as unconscious hatred towards women. Motherhood remains women's primary role, on average, in many communities around the world (Brogaard n.d.). They are required to raise children, care for the home and see to the needs of the family. In African societies and in the missionary era, women were also expected to undertake agricultural tasks to help feed the family. In settler society, too, it was not considered "feminine" to work outside the home, although some women did so to supplement the family income and help put food on the table. Patriarchy, as a societal system, depends on the loving mothers, good wives, loyal women, and heroines of a nation, while socialising them into a situation of political naivety (Kgatla 2019). As a system, patriarchy shapes gender norms and male expectations of women (Manne 2016a\&b). Frost (2016) sees patriarchy as a gendered political, social, and economic arrangement of power, while sexism refers to the cultural, interpersonal manifestation of patriarchy. Patriarchy employs stereotypes such as male chauvinism, contempt and aggression (if necessary), and, if it needs to, invites misogyny to "level the grass."

\section{Missionary Overtures in Perpetrations of Subtle Patriarchy}

Plaatjies-Van Huffel was particularly concerned with docility among URCSA women occasioned by patriarchy. She argued that the pervasive policy of apartheid was applied everywhere in society (Plaatjies-Van Huffel 2011; 2019). Mkhwanazi and Kgatla (2015) found the same docile attitude among the Manyano Women's Organisation of the Methodist Church of South Africa.

Religious organisations were also used as a vehicle for advancing the apartheid system. Churches, legal systems, and political and economic institutions were geared at promoting and implementing the system. Missionary churches in South Africa, such as the Methodist Church of South Africa, Dutch Reformed Church and Presbyterian Church, along with many others, established women's organisations that would aid their men counterparts in their mission campaigns (Mkhwanasi and Kgatla 2015). According to Madise (2008), the Manyano Women's Organisation started in 1844 as part of women's initiatives to create prayer homes for themselves, as they could not be accommodated under male leadership structures. For Beverley Haddad (2004), indigenous African Christian women in South Africa responded to the missionary endeavour through subversive action. They formed their own movement known as the Manyano (prayer union) movement. But by and large, the women's organisations created a site for women's struggle, as they could not occupy space in male leadership structures. Sometimes these were hijacked to serve the very oppressive structures they were fighting.

Within the DRC, the women's organisation called Women Mission League was founded on 21 March 1890 through the initiative of Emma Murray, the wife of pious minister 
Andrew Murray of the DRC, Wellington (cf. Plaatjies-Van Huffel 2011; 2019). Certainly, this innovation was copied from other churches, where it was seen to be working. Like mission station concepts, which were broadly used as a method in mission, it was acquired from other denominations or mission societies. For many missionary societies or churches, women's organisations would replicate themselves among indigenous people to accommodate the concept of not only male-dominated structures, but also separate women structures. In all mainline churches where these women's (Manyano) organisations operated, they were subjected to a myriad of stringent rules from male leadership and had to account for everything they did, including financial matters. Their programmes had to be approved before they could be implemented, and they were required to give reports to male structures on what they did (Mkhwanasi 2014). They were treated like irresponsible minors that could not do their work without strict supervision. Male ministers were appointed by the assemblies to supervise them and report about their activities in their various circuits. Andrews (1981) concludes that where male dominance has come to fruition, women do not need men to put them down or violate them, because they perpetuate male dominance themselves. Women can internalise misogyny to the extent that they frown on other women who resist the system of their subordination. Language was primarily used as a tool for the facilitation of oppression.

In her article on the institutionalisation of Christian women's organisations in the former Dutch Reformed Mission Church (DRMC) and the Dutch Reformed Church in Africa (DRCA), Plaatjies-Van Huffel $(2011,105-119)$ shows how subversive language can be used in the domestication of women. She argues that the values and norms of patriarchy were disseminated through lofty language such as referring to women as "mothers," "wives" and "daughters" of the nation (Plaatjies-Van Huffel 2011). Van Wyk (2010) portrays revivalist Angus Buchan of Greytown, KwaZulu-Natal-who regards (Afrikaner) woman as the heart of the house and the house as healthy as the woman who manages it — as the Billy Graham of South Africa.

Because of patriarchal systems, the women's organisations operate in such a way that often makes them docile instead of active agents for liberation. Manyano groups have generally been seen as conservative and apolitical in nature and thus are usually sidelined in feminist discourse. Instead, becoming a site of struggle, survival and resistance, that needs to be recognised as an influential space for indigenous women, the Manyano movement, more often than not, served the agenda of the oppressor.

Landman (2009) postulates that the system of the docility of women has helped Afrikaner leaders to preserve the ethos and way of life that was unique to them. Although rigid, they could evolve segregationist (Worden 2012, 20) thoughts through the employment of the Afrikaner Broederbond (Zaaiman 2010), Afrikaner nationalism, Afrikaner experience and Calvinism with the internal logic of eliciting the cooperation of women (Dobosova 2009, 310). The initiative to instil political indifference in and obtain the consent of women to male domination was not with "undersiders" but with 
"topsiders" and with the cooperation of the oppressed. The environment in which Afrikaner women found themselves was not conducive for feminism because it was not only subdued, but also non-virulent. A cloud of violent suppression always hanged over women's heads whenever men felt that they were losing their grip and becoming powerless.

Plaatjies-Van Huffel (2011) investigated the reason for this "invisibility" of women, and called for some explanation. South African society, she argued, is conventionally patriarchal (and this applies in varying degrees to all race groups). In other words, it was men who had authority in society; women were seen as subordinate. A woman's role was primarily a domestic one; it included child rearing and seeing to the well-being, feeding and care of the family. Women were not expected to concern themselves with matters outside the home - that was more properly the domain of men. Economic activity beyond the home (in order to help feed and clothe the family) was acceptable, but not considered "feminine" (Plaatjies-Van Huffel 2011).

\section{The Duality of Being Both Oppressor and Oppressed in the Church}

Plaatjies-Van Huffel was ordained in 1992 in a previously disadvantaged poor community. Her first experience in the community was that of rejection and not even being allowed to perform her ministerial functions as pastor (Plaatjies-Van Huffel 2011). Congregants not only refused her services, but left the church because of her presence. The schism occurred when 120 congregants, mostly women, who had been under the tutelage of male dominance for years, left the congregation and opted to join one which was headed by a male minister (Plaatjies-Van Huffel 2011). One would have expected women to embrace Plaatjies-Van Huffel, but instead they formed the group that rejected her. However, she remained resolute in facing the challenges in circumstances where the historically oppressed found the opportunity of having someone they could oppress. People exposed to an oppressive situation for a long time tend to internalise oppression and become worse oppressors themselves when they get the opportunity to do so (Garcia 2017). Jennifer Armstrong (2019) alludes to the same point when she says that internalisation of authoritarianism by the underside of the dynamic does not teach patience, but rather leads to extreme states of emotion and thinking. Some academic women, such as Plaatjies and Landman, in URCSA opted to resist the system although they had to endure backlash (Kgatla 2019).

\section{Betrayed Sincerity}

Often, Plaatjies-Van Huffel made wrong assumptions as a person. Often, she assumed that male-dominated church leadership would develop moderate gender sensitivity, especially because her church was based on a confessional stance. She presumed that URCSA would move away from being androcentric and amend church ruling guidelines (Plaatjies-Van Huffel 2011; 2019). She even went to the extent of submitting many amendments to the church constitution when she was serving as a church expert (lawyer). She pleaded for inclusive language that avoided gendered pronouncements. 
Little did she realise that patriarchal hegemony runs deep and wide in the church, and eradicating it is as difficult as making a left-handed person right-handed. One could compare the internalisation of patriarchy to left-handedness. In some African nations, left-handedness carries a stigma, as its use is construed as disrespectful, rude and dirty, which needs immediate correction (Alhassan 2018). Many tribal people in Africa would go to the extent of inflicting wounds on the left-handed in order to apply pain-correction. Sebastian Ocklenburg (2019) explains scientifically how left-handedness came about. $\mathrm{He}$ argues that handedness is caused by the brain, resulting from one form of functional hemispheric asymmetries, for example left-right differences in the brain. In left-handers, the motor cortex in the right side of the brain (the left side of the body is controlled by the right side of the brain, and vice versa) is dominant for fine motor behaviour. No amount of pain inflicted on the hand can change this arrangement.

In a similar way, the stubbornness of androcentric language with its masculine pronouns goes deeper than the tongue that pronounces them. People can adjust and be linguistically correct but still harbour the very stereotypes they mute in public. Changing patriarchy in society goes deeper than what catches the eye. Radicalised educational programmes for changing behaviour should start at a tender age and be rigorously monitored by parents, teachers and society (Wilner and Dubouloz 2011).

Plaatjies-Van Huffel suffered double oppression in her church. Her educational standards, bravery in challenging the status quo, insistence on inclusivity, outspokenness, articulation, and ability to do better than her male counterparts in leadership positions, disadvantaged and oppressed her. The church professed reconciliation, unity and justice, but contradicted itself in practice. Plaatjies-Van Huffel's presence, ability to articulate and speak truth to power meant she was seemingly not eligible for a leadership position (Kgatla 2020).

\section{A Lioness in the Leadership of URCSA}

Metaphorically, she was called a "lioness" by one of the moderators, Prof. S. T. Kgatla (Plaatjies-Van Huffel 2011; 2019). She could be compared to a lioness because she worked very hard for the church. A lioness will hunt and kill prey to provide for her pride and she is more strategic (brainy) in her hunting expeditions. Lionesses indeed do the majority of the hunting. She is fast; much faster than a male lion. The advantage for a lioness (as far as hunting goes) is that she stays hidden as long as possible, slinking along on her belly when necessary, staying hidden in the grass in order to get as close to the prey as possible. It always starts with the lioness taking position on the flank. Plaatjies-Van Huffel was called lioness because she was an excellent church expert for two terms; critical about church insensitivity to issues addressed by the Belhar Confession and always putting men on their toes with questions she was posing in meetings. In unification talks within the family of the Dutch Reformed Churches she would raise objections if the discussion was against the principle of church law and gender inclusivity. She called a spade a spade with such gentleness that few would take offense to what she was saying. 
In 2012, she was elected to the position of moderator for the whole church. Many heralded her election as a change of heart for good in URCSA. In 2013, she was elected to represent the southern African region at the All Africa Conference of Churches in Kampala, and, in the same year, was chosen to represent Africa on the World Council of Churches. One would be misled into believing that African patriarchy was defeated, but the "lions were still asleep." Three years later, when she was seeking a second term as the moderator of URCSA, Plaatjies-Van Huffel was defeated in a humiliating manner. Voting for office bearers at the general synod was prepared "slate"; and she was not in any of the slates. With her experience as church law expert for two terms, representative of the Cape Synod in their regional leadership, deputy moderator for the general synod, moderator of the same synod, Africa President on WCC, professor of church polity and church history at one of the prestigious and distinguished institutions, she should have been elected for the second term. Despite all these humiliating experiences, Plaatjies-Van Huffel remained humble and loyal to her church. At her untimely death she received accolades from all (male and female from URCSA).

\section{Towards a Concluding Summary}

This research attempted to trace the hostile environment occasioned by the coming to power of the Nationalist Party and the resultant introduction of institutionalised apartheid in the early 1950s. Plaatjies-Van Huffel was born into such a world. The constituent factors of that time, apartheid oppression, the patriarchal androcentric environment (with its surrogates, sexism, misogyny, machismo and marianismo) and blatant classism were applied indiscriminately. These manifested themselves in all hierarchical echelons of power. Women of social standing were forced to bear the brunt of it.

In her situation in the leadership meetings of URCSA, Plaatjies-Van Huffel saw men who sympathised with her but would not dare voice their disapproval of how the church treated her at meetings. Instead, they would express their displeasure outside of these meetings. All her ecclesiastical advice over the period was openly rejected and she was belittled as someone who did not know what she was doing. Because of her threat to male dominance and the fear of women, her presence triggered real schizophrenic tendencies. Her presence was not only construed as challenging to the male dominated environment, but also eroded any form of confidence the leadership had on women's empowerment in the church.

This article articulated the role of patriarchy, misogyny and sexism in ordering conformity in society and explored how these affected women in South Africa. In dialogue with Plaatjies-Van Huffel, and in response to her contribution, I have attempted to show how tripartite oppression affected her life. The paper further pinpointed some gaps in her theology that did not fully grasp the depth and extent of the indelibility of patriarchy in society, as she tried to locate the role of the androcentric use of language. Use of masculine pronouncements is just the tip of the iceberg; the real mountain 
remains submerged. Factors such as one's own security, self-preservation and avoidance of chastity played a role in the submission of women to male rule.

The life and experience of Plaatjies-Van Huffel as a minister of religion, a church law expert and, finally, the moderator of the church was monitored, controlled and guided by her male counterparts. Misogyny, which is employed in the service of patriarchy, has been embedded in all societies inhabiting the earth (Kimberly 2006, 127-128) and hides its viciousness by creating a false consciousness of orderly society through policing compliance. Instead of openly showing hostility or hatred toward women, misogyny controls and tames those who challenge male dominance (Campbell 1981); it rewards women who reinforce the status quo and punishes those that dissent (Manne 2020). Within the context of a patriarchal society, inhumane social arrangements that control the lives of women are taken as normal and making sense. Women are expected to be passive or docile. Finally, the article articulates the bravery with which Plaatjies-Van Huffel exercised her prophetic witness. Like a lion, she took initiatives in challenging male members to fiercely tackle their tasks.

\section{References}

Alhassan, A. B. 2018. "Left-handedness and Stigmatization in Africa: Implications for Parents and Teachers." Global Journal of Archaeology and Anthropology no. 7 (3). https://doi.org/10.19080/GJAA.2018.07.555713.

Ally, Y. 2015. "“Burn the Witch': The Impact of the Fear of Witchcraft on Social Cohesion in South Africa." Psychol. Soc., no. 49: 25-45. https://doi.org/10.17159/23098708/2015/n49a3.

Andrews, R. J. 1981. “The Mist of Misogyny.” Unpublished paper.

Armstrong, J. 2019. "Why Do the Oppressed, once Empowered, often Become worse than the Oppressor?" Quora, 28 March 2019. Accessed August 1, 2020.

https://www.quora.com/Why-do-the-oppressed-once-empowered-often-become-worsethan-the-oppressors.

Brogaard, B. n.d. "The Mysteries of Love: Insights into the Psychology of Love.” Psychology Today. Accessed August 4, 2020. https://www.psychologytoday.com/za/blog/themysteries-love.

Campbell, J. R. N. 1981. "Misogyny and Homicide of Women." Advances in Nursing Science 3 (2): 67-86. https://doi.org/10.1097/00012272-198101000-00007.

Coaston, J. 2019. “The Intersectionality Wars.” Vox, 28 May 2019. Accessed August 4, 2020. https://www.vox.com/the-highlight/2019/5/20/18542843/intersectionality-conservatismlaw-race-gender-discrimination.

Dobosova, J. 2009. "Calvinism in the Context of the Afrikaner Nationalist Ideology." Asian and African Studies 18 (2): 305-323. 
Flaendorp, C. 2014. "The Life and Times of Professor Mary-Anne Plaatjies-Van Huffel: A Transformative Church Leader in Sub-Sahara Africa." Studia Historiae Ecclesiasticae 40 (1): 53-64.

Frost, A. 2016. “The Logic of Misogyny.” Boston Review. Accessed March 2, 2018. http://bostonreview.net/forum/kate-manne-logic-misogyny.

Garcia, E. V. 2017. "The Duality of Being Both Oppressor and Oppressed in Different Places." Innova Research Journal 2 (3): 38-90. https://doi.org/10.33890/innova.v2.n3.2017.134.

Goloba-Muteni, F. 2005. "Witchcraft, Social Cohesion and Participation in a South African Village.” Development and Change 36 (5): 937-958. https://doi.org/10.1111/j.0012155X.2005.00442.x.

Haddad, B. 2004. "The Manyano Movement in South Africa: Site of Struggle, Survival and Resistance." Agenda 18 (61): 4-13.

"How Should South Africa Remember the Architect of Apartheid?" Accessed August 7, 2020. https://www.smithsonianmag.com/history/how-should-south-africa-remember-architectapartheid-180960449/.

Johnson, W. R. 1994. Dismantling Apartheid: A South African Town in Transition. London: Cornell University Press. https://doi.org/10.7591/9781501721830.

Kgatla, S. T. 2019. “"The piety of Afrikaner women’: In conversation with Prof. Christina Landman on the piety of Afrikaner women." HTS Theological Studies 75 (1): 1-7. https://doi.org/10.4102/hts.v75i1.5427.

Kgatla, S. T. 2020. “Addicts of Gender-based Violence: Patriarchy as the Seed-bed of Gendered Witchcraft Accusations." Upcoming article in Studia Historiae Ecclesiasticae to be published in 2020 .

Kgatla S. T., and A. Magwira. 2015. "The Defining Moments for the Dutch Reformed Church Mission Policy of 1935 and 1947." Missonalia no. 43 (3). https://doi.org/10.7832/43-3109.

Kimberly, H. 2006. "Book Review: Misogny: The Male Malady." Journal of Cultural Studies 9 (1): 127-128. https://doi.org/10.1177/136754940600900110.

Korn, E., S. Lander, and R. Lander (eds). 2010. “Jewish Understanding of Other.” Accessed August 4, 2020.

https://www.bc.edu/research/cjl/cjrelations/backgroundresources/jsourcebook.html.

Landman, C. 2009. "Calvinism and South African Women: A Short Historical Overview." Studia Historiae Ecclesiasticae 35 (2): 89-102. 
Madise, M. J. S. 2008. “The Manyano Movements within the Methodist Church of Southern Africa: An Expression of Freedom of Worship.” Studia Historiae Ecclesiasticae 34 (2): $117-126$.

Manne, K. 2016a. “The Logic of Misogyny.” In Boston Review. Accessed March 2, 2018. http://bostonreview.net/forum/kate-manne-logic-misogyny.

Manne, K. 2016b. "Forum Response to 'The Logic of Misogyny'." Boston Review, 11 July. Accessed March 20, 2018. bostonreview.net/julyaugust-2016.

Manne, K. 2020. “'Down Girl’: The Logic of Misogyny.” New York: Oxford University Press.

Mkhwanazi, F. S. 2014. "Women Ministers in Mission: With Reference to the Methodist Church of Southern Africa." PhD thesis, Department of Missiology and Religion, University of Pretoria.

Mkhwanazi, F. S., and S. T. Kgatla. 2015. "The Place of Woman Ministers in the Mission of the Methodist Church of Southern Africa.” Studia Historiae Ecclesiasticae 41 (2): 180197. https://doi.org/10.25159/2412-4265/130.

Napikoski, L. 2020. "Patriarchal Society According to Feminism.” Accessed July 23, 2020. https://www.thoughtco.com/patriarchal-society-feminism-definition-3528978.

Ocklenburg, S. 2019. “The Left-Handed Brain.” Psychology Today, 6 September 2019. Accessed August 2, 2020. https://www.psychologytoday.com/za/blog/the-asymmetricbrain/201909/the-left-handed-brain.

Parrinder, G. 1963. Witchcraft: European and African. London. Faber and Faber.

Pirani, A. 1992. “Gender and Patriarchy.” Accessed July 30, 2020.

https://link.springer.com/chapter/10.1057/9780230372801_4.

Plaatjies-Van Huffel, Mary-Anne E. 2011. “The Institutionalisation of Christian Women's Organisations: From Docile Recipients to Agents of Change." Studia Historiae Ecclesiasticae 37 (1): 105-119.

Plaatjies-Van Huffel, Mary-Anne E. 2019. “A History of Gender Insensitivity in URCSA. Studia Historiae Ecclesiasticae 45 (3). Accessed March 30, 2020. http://dx.doi.org/10.25159/2412-4265/6250.

Popadiuk, N. 2004. "The Feminist Biographical Model in Psychological Research.” The Qualitative Report 9 (3): 392-412.

"Race Relations Survey 1962-1977.” Accessed July 20, 2020. http://psimg.jstor.org/fsi/img/pdf/t0/10.5555/al.sff.document.boo19780000.042.000_final. pdf. 
South African History Online. "South Africa Celebrating 20 Years of Democracy 2019." Accessed July 20, 2020. https://www.sahistory.org.za/archive/south-africa-celebrating-20years-democracy.

Van Wyk, M., 2010. "Angus Buchan: 'Die Vrou is die hart van die Huis'.” Netwerk24, 20 April 2010. Accessed August 4, 2020. https://www.netwerk24.com/Sarie/Bekendes/OnsPraat-Met/angus-buchan-die-vrou-is-die-hart-van-die-huis-20170914.

Weldon, L. 2019. Untitled post. Medium, 12 March 2019. Accessed April 2, 2020. https://medium.com/@ lweldon/patriarchy-is-a-social-system-in-which-men-hold-primarypower-and-predominate-in-roles-of-67558f4f3087.

Wilner, A. S., and C. J. Dubouloz, 2011. "Transformative Radicalisation: Applying Learning Theory to Islamist Radicalisation.” Accessed December 12, 2020. https://www.tandfonline.com/doi/abs/10.1080.

Wingfield, A. H. 2009. "Intersectionality Theory.” Accessed July 28, 2020. http://scholar.google.co.za/scholar?q=Adia Harvey Wingfield (2009) defines intersectionality theory \&hl=en\&as_sdt=0\&as_vis=1\&oi=scholar.

Worden, N. 2012. The Making of Modern South Africa. London: Blackwell.

Zaaiman, J. 2010. "The Local Role of a Wellington Afrikaner Broederbond Branch, 19371994." Historia 55 (2): 121-146. 